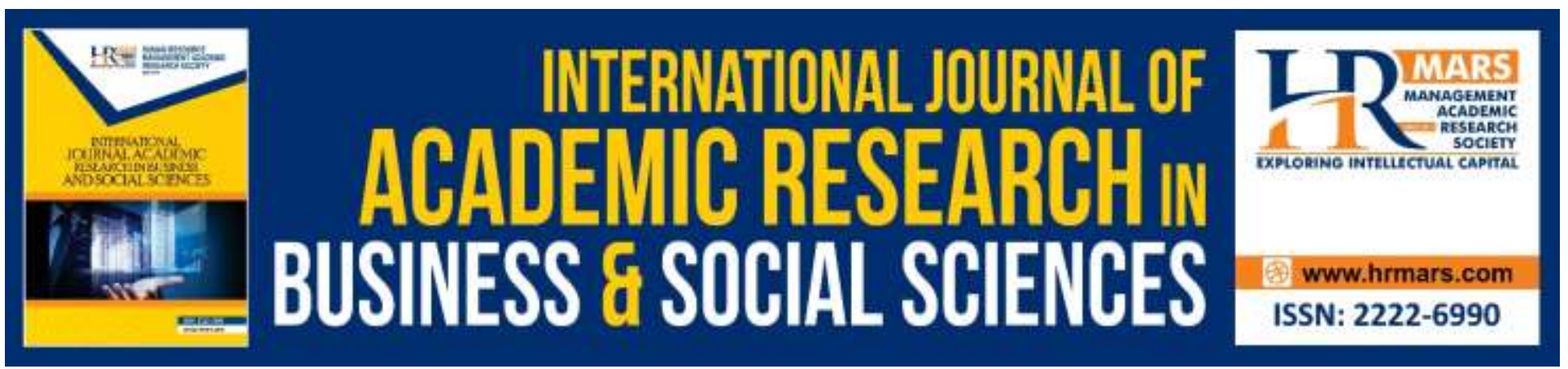

\title{
The Muslim Community's Perception of Religious Studies in Selangor State Mosques
}

Abd Hadi Borham, Mohamad Marzuqi Abdul Rahim, Wahyu Hidayat Abdullah

To Link this Article: http://dx.doi.org/10.6007/IJARBSS/v8-i12/5764

DOI: $10.6007 /$ IJARBSS/v8-i12/5764

Received: 02 Nov 2018, Revised: 13 Dec 2018, Accepted: 21 Dec 2018

Published Online: 28 Dec 2018

In-Text Citation: (Borham, Rahim, \& Abdullah, 2018)

To Cite this Article: Borham, A. H., Rahim, M. M. A., \& Abdullah, W. H. (2018). The Muslim Community's Perception of Religious Studies in Selangor State Mosques. International Journal of Academic Research in Business and Social Sciences, 8(12), 258-279.

Copyright: (C) 2018 The Author(s)

Published by Human Resource Management Academic Research Society (www.hrmars.com)

This article is published under the Creative Commons Attribution (CC BY 4.0) license. Anyone may reproduce, distribute, translate and create derivative works of this article (for both commercial and non-commercial purposes), subject to full attribution to the original publication and authors. The full terms of this license may be seen at: http://creativecommons.org/licences/by/4.0/legalcode

Vol. 8, No. 12, 2018, Pg. 258 - 279

Full Terms \& Conditions of access and use can be found at http://hrmars.com/index.php/pages/detail/publication-ethics 


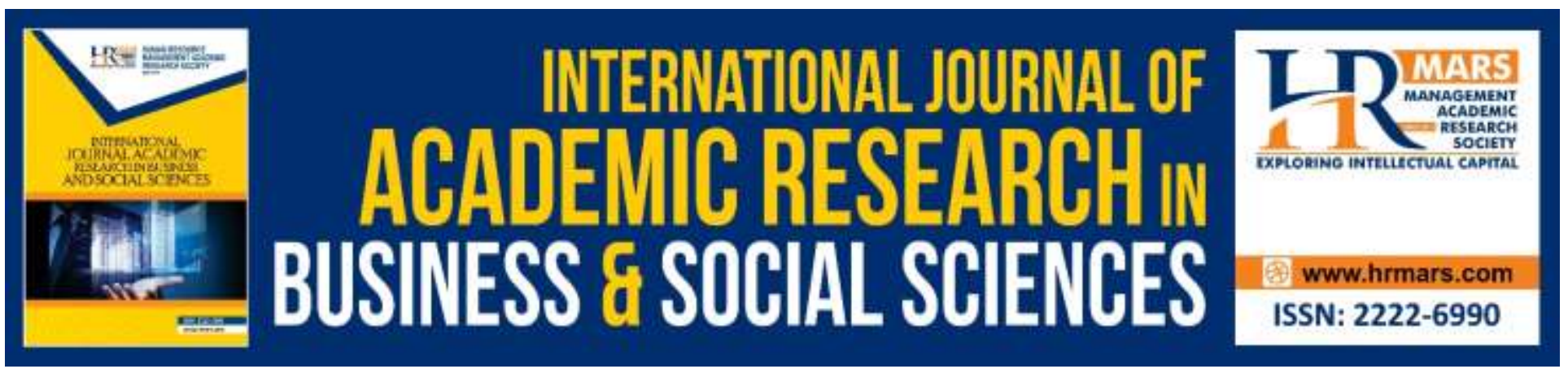

\title{
The Muslim Community's Perception of Religious Studies in Selangor State Mosques
}

\section{Abd Hadi Borham, Mohamad Marzuqi Abdul Rahim, Wahyu Hidayat Abdullah}

Faculty of Human Sciences, Sultan Idris Education University (UPSI), Tanjung Malim, Perak

Malaysia

\begin{abstract}
The aim of this research is to identify respondents' perception of religious study toward educators in terms of readiness, materials, presentation, and character in Selangor state mosques. The research was analysed using quantitative research design using questionnaires. 400 respondents were chosen through cluster sampling. The questionnaires were distributed in three district zones in the state of Selangor. Results were descriptively and inferentially analysed with the values of frequency, percentage, mean value, t-test, and ANOVA. Results show that respondents' perception of educators' readiness shows high mean value (3.77), perception of materials shows average mean value (3.33), perception of presentation shows average mean value (3.41), and perception of educators' character shows average mean value (3.43). The results indicate that religious study at mosques has given a value in lifelong learning towards the Muslim community. Although respondents' perception towards it is still at an average level, however, this could indirectly affect them in terms of acceptance of understanding, and appreciation towards the religion. The results of this study contribute to the improvement of the management of mosque institutions in the aspect of curriculum development which incorporates lifelong learning or adult learning (andragogy), faculty management, and understanding of the subject required for the Muslim community.
\end{abstract}

Keywords: Perception, Religious Studies, Mosque, Selangor State

\section{Introduction}

Religious studies in the mosque are one of the lifelong learning forms to enhance knowledge, awareness, experience and skills. Religious studies in the mosque are described as informal education because they do not have specific curriculum and their learning. The form of non-formal education is organized on the basis of the needs of its participants, including the young, adult or old (Fakhrul Adabi, 2009). Taylor (2006) explains that informal education is a learning activity instituted and usually implemented without systematic structure and curriculum and does not involve the recognition of recognized certificates. Such learning is an alternative to those who do not have the opportunity to pursue formal studies (Adanan Junoh et al., 2013). In addition, religious studies in the 
mosque are also related the demands of knowledge in Muslim life (Safinah Ismail et al., 2015). Every Muslim should not neglect the importance of knowledge even in old age. Even if it is necessary to have a malicious nature with knowledge as explained by the Prophet s.a.w in the hadith narrated by al-Bukhari (6608):

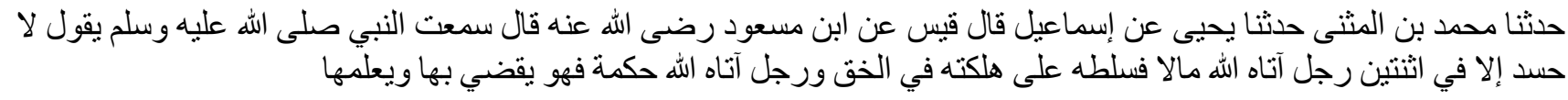

Meaning: Narrated by Ibn Mas'ud r.a said: "I heard the Prophet s.a.w said: "Do not be jealous of two things. A person whom Allah has given him of wealth and he has mastered it and spent it in the right way and someone whom Allah has given wisdom and he performs it and teaches it (to others)."

The Prophet s.a.w mentions that one can be malicious (al-hasad) to another person in two things only: people are given the gift of the property and spent on the right path; and people are endowed with knowledge and practice and are taught to others. This shows the concept of learning as stated by the Prophet s.a.w is intended so that Muslims always make knowledge as a priority in their lives. Therefore, religious studies at the mosque are included in lifelong learning of informal education and adult learning aimed at enhancing understanding and knowledge in the appreciation of religion in line with the law.

According Ibn Khaldun, the development of a society has always been strongly influenced by education. In his writings in the title book 'Muqaddimah,' Ibn Khaldun presents social ideas from the natural patterns of human life. He has made comparisons between individual education that dwells in urban and rural areas. Individuals in the interior are more courageous as they are educated with independent education with a combination of self-care, ready to face challenges in maintaining family and relatives. People who are educated in urban areas are in accordance with the needs or pressures in family life, teaching and career situations, and social or political life (al-Na'miy, 1994).

Ibn Khaldun has discussed the education topic of taqlid, muhakah and iqtida (obedience). He described the effects of society on the three aspects. Taqlid and muhakah are natural things or nature in humans, for example taqlid children to their families, taqlid part of man to others, taqlid new genes to the past and taqlid generation of pupils to their teachers (al-Na'miy, 1994). This shows that the effects of environmental patterns affect the way human education. The essence of man is that it has the same characteristics and is more inclined to the characteristics of goodness due to the basis of its occurrence. Ibn Khaldun also focuses on the importance of the environment and the social environment in forming behaviour, thinking and intelligence. The difference between civilized humans and rural people is method in teaching, training and material environment.

In the context of adult learning method, Ibn Khaldun has laid down several as follows: 
1) Gradually: Transfer of knowledge is more effective with gradual methods. At that time, the result was a knowledge of the students. However, it is still weak and requires the students to understand the subject and get the whole question.

2) Continuing: Expanding and deepening knowledge: It is a continuation of the first stage. In this stage, a simple description method cannot be used. It should be elaborated by involving all angles such as disagreement and explanation.

3) Comprehensive: The approach is repeated to the students even though they already understand. Avoid ambiguities except for clarity. These three steps are a series of links and knitting together (AlNa'miy, 1994).

Al-Rawiy states some of the features of adult education or continuous education based on Islam, which is a lifelong learning process from "cradle to the grave." Second, repetitive learning is the practice of early Muslims. This is because in the early of Islamic civilization, the formal education system was not today, as individuals often learn and work in exchange for time. This is because in learning there are words of wisdom such as "A person is not perfect if he does not study, and does not become educated if he does not do anything according to what is learned." Third, the concept of learning society is a claim in Islam and become a culture in the history of Islamic civilization (Safinah Ismail et al., 2015). In the era of Umayyad caliphate, the city of Andalus was the symbol of education for the European community during the Islamic era. At that time, the European community still experienced dark ages and the city of Andalus became an attraction for non-Muslims in Europe (Shanaz Husain, 2004).

While, the religious courses offered at all levels. Today the adult learning are also known as the andragogy learning that guides the adult humans. According McCulloch (2014), Alexander Kapp was the first person to use the term andragogy by presenting certain characteristics while being a teacher in high school in Germany. Kapp has emphasized the importance of education among adults so that educational developments will always take place at all levels of the human race. In many countries today, andragogy is introduced as a developmental concept in support of lifelong learning by focusing on adults. In the UNESCO general conference (1976), andragogy is characterized by adult learning that involves the entire planned educational process in content, stage and format. It aims to pursue or replace basic education at schools, colleges and universities where one is regarded as adults by the community in developing skills, enriching knowledge and improving technical and professional qualifications and consequently leading to changes in attitudes, self-development, involvement in social, economic development and culture (Mohd Azhar Abdul Hamid, 2004). The concept of andragogy learning based on assumptions as follows:

i. The person wish to know: Adults need to know why they need to learn. Tough (1979) found that the ability of adults to learn to benefit from their learning and to take into account the disadvantages if not studying them. 
INTERNATIONAL JOURNAL OF ACADEMIC RESEARCH IN BUSINESS AND SOCIAL SCIENCES

Vol. 8, No. 12, Dec, 2018, E-ISSN: 2222-6990 @ 2018 HRMARS

ii. The self-improvement: Adults have their own perfection and are able to judge their own decisions and determine their own lives. Adults are also working to develop their psychological needs for attention and appreciation from others.

iii. Experience: Adults have a wealth of experience gained from adolescence. This experience varies according to the background, learning, needs, achievement and interest. Frequently used learning methods are group discussion, problem solving and exchange of opinions.

iv. Willingness: Adults are ready to learn what they need to know and learn and associate what they learn with the reality of life. The willingness of learning is important for self-development.

v. Learning Orientation: Adults are learning life-centered and are different from children who are focused on subject or subject-centered. Everything learned is related to their life.

vi. Motivation: Adults get motivation from outside such as promotion, salary and others. But internal factors have a strong influence on learning such as quality of life and appreciation. Tough (1979) found that adults are always motivated for self-growth and development, but this motivation often fails because there is a negative concept in the student, limited time and the accompanying program does not conform to the principles of adult learning (Mohd Azhar et al., 2004; Abd Kadir Ariffin, 2007).

In this context, the mosque is one of the institutions that offer religious studies since the early. There are many examples of mosques in the history of Islamic civilization that have played an important role in the development of knowledge. Masjid al-Haram is one of the mosques that many of scholar in the Islamic world including in the Malay Archipelago. Similarly, the al-Nabawi Mosque in Madinah was once the place where the Prophet s.a.w taught al-Quran and al-hadith to his companions such as Abu Bakr al-Siddiq, Umar al-Khattab, Uthman bin 'Affan, Ali bin Abi Talib, Khalid Ibn al-Walid, Saad bin Abi Waqqas, Abu Ubaidah and etc. The system of halaqah studies has been used today (Mohd Muhiden Abd Rahman et al., 2009). The halaqah or circle system of learning continues to evolve during the Islamic civilization. The halaqah in mosques have grown in government palaces and magnificent houses. In this system, the teacher will sit on a small piece of wood or a chair made of wood. Students will surround the teacher in the form of a circle and in a certain order. Each student has his or her own position as an excellent student in the right and left side of the teacher. One corner will be emptied specifically to people who hear spontaneously or do not attend regular studies (Ali Mohamad, 1997).

In Malaysia, mosque religious studies have been implemented since the growth of Islam in the Malay Archipelago (Rahim et al., 2018). The mosque is not a place to perform ritual worship, even used as centre of knowledge to all levels of society. Religious studies in the mosque institutions is a form of informal study for increasing or improving the quality of Islamic understanding among the society. Today, the religious studies in the mosque has good response among the Muslim community in Malaysia. The past study also show that the positive impact of religious studies but still based on locality such as urban area. For the involvement aspect, the findings of the previous studies show 
that the majority of the group level such as youth, middle and old are studying at the mosque (Azmi Shah Suratman et al., 2014; Engku Ahmad Zaki Engku Alwi 2008; Suhadak Mahmud et al. 2013). But the level of understanding of the study is still less consistent with the background of acceptance of religious knowledge. Omar Zakaria (2012) found that the mosque was more focused on syarah method based on the teacher books. However, the effectiveness of the religious studies in the mosques is space of facilities provided. Alias Azhar (2013) found that the religious studies such as fiqh studies are needed with more interesting method of teaching. It must related to the current issues of the world and emphasized the thinking skills in teaching and learning process. The proposed of methods and techniques in teaching and learning are lecture, memorization, demonstration, discussion and problem solving techniques. Ab Halim Tamuri et al. (2012) states that religious studies that serve as a life-long learning platform in the mosque is the continuation of formal education in formal educational institutions. But the combination between these two institutions seems to be conflict of objective in education today.

The mosque studies are conducted by qualified teachers focusing on four areas of knowledge tauhid, fiqh 'ibadah, tafsir and tasawuf. The religious mosque studies has provided opportunities for the community to understand Islam continuously (Shuhadak Mahmud et al., 2014). However, the study at the mosque has not yet been used by a specific module and is suitable for adult learning. It still depends on the teaching materials of different teachers and sometimes the topics discussed often overlap. Adult learning involving the entire process of organized education in content, level and format, techniques and delivery tools, materials usage, community acceptance and knowledge with current issues (Engku Ahmad Zaki Engku Alwi, 2008). It important for strength the religiosity with the challenges of ICT or globalization such as misunderstanding of Islamic knowledge, extreme and liberal thought that may affect the aqidah aspect (Abd Hadi Borham, 2009). The religious studies in the mosque are often showed with a less positive picture due to the teacher's aspect and teaching method on learning and teaching process. Therefore, this study aims to identify the respondents' perceptions of instructors, materials, delivery and skills. There are six hypotheses that are presented as below:

H1: There are not significant difference in the mean score of the respondents perceptions based on gender towards the teaching personality.

$\mathrm{H} 2$ : There are not significant difference in the mean score of respondents age perceptions based on the age of the materials used by the educators.

H3: There are not significant difference in the mean score of the respondents perceptions based on the educational background of the teaching method.

H4: There are not significant difference in mean score of respondents perceptions based on employment and time of religious studies at the mosque.

$\mathrm{H} 5$ : The readiness of educators has no significant correlation with lecture methods. 


\section{Research Methodology}

This study uses a quantitative study design. Quantitative research data can be measured by numbers. According to Chua (2006) the data obtained through surveys (questionnaires) will be translated numerically based on the scale or statistical techniques in the research in measuring a situation. This study uses random sampling at random with cluster method technique. According to Fauzi Hussin et al. (2014) the whole of population divided into groups and a random sample is used to sample in each selected group. The respondents were selected according to the division of zones in the mosques of each district in Selangor as shown in Table 1.

\section{Table 1. Zone of Mosque}

\begin{tabular}{|clc|}
\hline Zone & \multicolumn{1}{c|}{ District } & Mosque \\
\hline First & $\begin{array}{l}\text { Hulu Selangor } \\
\text { Kuala Selangor } \\
\text { Sabak Bernam }\end{array}$ & 10 \\
\hline Second & $\begin{array}{l}\text { Klang } \\
\text { Petaling Jaya } \\
\text { Gombak }\end{array}$ & 10 \\
\hline Third & $\begin{array}{l}\text { Kuala Langat } \\
\text { Hulu Langat } \\
\text { Sepang }\end{array}$ \\
\hline & Total & 10 \\
\hline
\end{tabular}

The questionnaire was used to obtain information from the sample according to the purpose of the study. Questionnaires were distributed in 30 mosques according to the zone. A total of 400 respondents have been selected as respondents as shown in Table 2. Respondents selected consist of mosque members who follow religious studies in their respective districts.

Table 2. Number of Respondents

\begin{tabular}{|ll|c|}
\hline \multicolumn{2}{|c|}{ District of Zone } & Respondent \\
\hline First & Hulu Selangor, Kuala Selangor dan Sabak Bernam & 130 \\
\hline Second & Klang, Petaling Jaya dan Gombak & 135 \\
\hline Third & Kuala Langat, Hulu Langat dan Sepang & 135 \\
\hline \multicolumn{2}{|c|}{ Total } & 400 \\
\hline
\end{tabular}

Table 2 shows 130 respondents of first zone districts were obtained at Hulu Selangor, Kuala Selangor and Sabak Bernam. Respondents in the second zone were 135 persons (34 percent) and third with 135 persons (34 percent). The second and third zones include respondents at the Klang, Petaling Jaya, Gombak, Kuala Langat, Hulu Langat and Sepang districts. This shows that the respondents at the second and third zone zones are the highest than total of respondents in the first zone. 


\section{Result}

The results of this study has been analysed with frequency, percentage, mean score, $t$ test and analysis of one way variant (ANOVA). Descriptive analysis is also measured based on the mean score interpretation to indicate the level of respondents consent to the items. The mean score of 1.00 to 2.33 is the high level, value for 2.34 to 3.66 is the moderate level and the mean score 3.67 to 5.00 is the low level as shown in Table 3.

Table 3. Score Mean Interpretation

\begin{tabular}{|l|c|}
\hline Mean score & Interpretation \\
\hline 1.00 to 2.33 & Low \\
\hline 2.34 to 3.66 & Moderate \\
\hline 3.67 to 5.00 & High \\
\hline
\end{tabular}

Source: Modified from Jamil Ahmad (1993)

\section{(a) Distribution of Respondents Demographics}

The total sample of the study was obtained by 400 respondents. Respondents were chosen purposively sampling at 30 mosques in Selangor. The results showed that the number of respondents who answered the questionnaire was 317 (79.3 percent), while the respondents were 83 (20.8 percent), as shown in Table 4. This shows that the number of male respondents is higher than female respondents with a percentage of 58.5 percent.

In terms of age, 10 (2.5 percent) respondents were under 20 years old. Meanwhile, 61 respondents ( 15.3 percent) aged between 21 to 30 years old, 68 respondents ( 17 percent) were aged 31 to 40 years old, 90 respondents (22.5 percent) aged 41 to 50 years old and 171 respondents (42.8) aged 51 years and above. This shows that the age category 51 years old is the highest respondent in this study. Respondents aged 41 to 50 years are the second highest and respondents from age group 31 to 40 are the third highest, as shown in Table 4. However, this finding shows that respondents aged 20 years and above are the highest in the study group. This age group consists of youth, adult and old.

In term of education level, 135 people (33.8 percent) of respondents with educational background in bachelor or masters and 122 (30.5 per cent) in diploma and Malaysian Higher Education Certificate (STPM) level. This shows that almost 65 percent of respondents have educational backgrounds from higher education institutions. Meanwhile 63 (15.8 percent) respondents had an education level at Malaysian Certificate of Education (SPM) and Malaysian Vocational Education Certificate (SPVM); and 58 (14.5 per cent) respondents had an educational background at the Lower Secondary Assessment (PMR) level. A total of 11 (2.8 percent) respondents at pondok system or madrasah school level and 11 (2.8 percent) respondents at primary school level, as shown in Table 4.2. This shows that almost 31 percent of respondents have education level at secondary school level and almost 6 percent of respondents have education levels pondok system, madrasah and primary school. 
In term of employment, 127 respondents (31.8 percent) were government employees, 97 respondents (24.3 percent) were private employees, 80 respondents (20 percent) were selfemployed and 96 respondents ( 24 percent) retired as shown in Table 4.2. This shows that 56 percent of respondents are employed under government and private employers and 20 percent of respondents are self-employed or entrepreneurs.

In term of position in the mosque, 23 respondents (5.8 per cent) are imams, 17 respondents (4.3 per cent) as bilal or muazzin, 129 respondents (32.2 per cent) as mosque committee member and 16 respondents ( 4 per cent) as former of committee mosque member as shown in Table 4.2. This shows that 10 percent of respondents consisted of priests and bilal; and almost 37 percent of the respondents are those who are members of mosque committee members and have been members of the mosque committee. Meanwhile, 215 respondents (53.8) did not have any posts at the mosque.

Table 4. Respondent Demographics

\begin{tabular}{|c|c|c|c|c|}
\hline Num. & & Demographic & Total & Percent \\
\hline \multirow[t]{3}{*}{ A1. } & Gender & Male & 317 & 79.3 \\
\hline & & Female & 83 & 20.8 \\
\hline & & Total & 400 & 100.0 \\
\hline & Age & Under 20 years old & 10 & 2.5 \\
\hline & & $21-30$ years old & 61 & 15.3 \\
\hline & & $31-40$ years old & 68 & 17 \\
\hline & & $41-50$ years old & 90 & 22.5 \\
\hline & & 51 years old and above & 171 & 42.8 \\
\hline & & Total & 400 & 100 \\
\hline \multirow[t]{7}{*}{ A3. } & Level Education & $\begin{array}{l}\text { Bachelor \& } \\
\text { Postgraduate }\end{array}$ & 135 & 33.8 \\
\hline & & Diploma \& STPM & 122 & 30.5 \\
\hline & & SPM \& SPVM & 63 & 15.8 \\
\hline & & PMR & 58 & 14.5 \\
\hline & & Pondok \& Madrasah & 11 & 2.8 \\
\hline & & Primary school & 11 & 2.8 \\
\hline & & Total & 400 & 100 \\
\hline \multirow[t]{4}{*}{ A4. } & Employment & Government & 127 & 31.8 \\
\hline & & Private sector & 97 & 24.3 \\
\hline & & Self-employed & 80 & 20 \\
\hline & & Retire & 96 & 24 \\
\hline
\end{tabular}


INTERNATIONAL JOURNAL OF ACADEMIC RESEARCH IN BUSINESS AND SOCIAL SCIENCES

Vol. 8, No. 12, Dec, 2018, E-ISSN: 2222-6990 @ 2018 HRMARS

\begin{tabular}{|lllcc|}
\hline & & Total & 400 & 100 \\
\hline \multirow{3}{*}{ A5. } & Post in mosque & Imam & 23 & 5.8 \\
& & Bilal & 17 & 4.3 \\
& & Mosque committee & 129 & 32.3 \\
& & member & \\
& & Former mosque & 16 & 4 \\
& & committee member & 215 & 53.8 \\
\hline & Non post & 400 & 100 \\
\hline \multirow{4}{*}{ A6. Distance of home from mosque } & Total & & \\
& & Less than 500 metre & 164 & 41.0 \\
& & 500 metre - 1 KM & 154 & 38.5 \\
& & More than 1 KM & 74 & 18.5 \\
& & Less than 5 KM & 8 & 2.0 \\
\hline & & Total & 400 & 100 \\
\hline \multirow{2}{*}{ A7 } & Frequently attend to the mosque & Always (5 times) & 96 & 24.0 \\
& & Often (4-5 times) & 95 & 23.8 \\
& & Quite often (2-3 times) & 129 & 32.3 \\
& & Sometime (1 time) & 80 & 20.0 \\
\hline & & Total & 400 & 100 \\
\hline
\end{tabular}

(b) Participation in Religious Studies at the Mosque

Table 5 shows the participation of respondents in religious studies at the mosque. For items (B1) the findings show that 284 (71 percent) of respondents have participated in religious studies at the mosque. Most respondents participate in studies with frequencies 4 to 5 times a week. While 116 respondents (29 percent) respondents followed religious studies with frequency 1 to 3 times a week. This finding shows the participation of respondents in religious studies is positive. For the items (B2), the findings showed that 143 respondents (35.8 percent) stated that the problems faced in religious studies were due to time constraints, 58 respondents ( 14.5 percent) stated that they were busy with family affairs, 47 respondents (11.8 percent) tired, 3 respondents ( 8 percent) expressed embarrassment, and 149 respondents (29.9 percent) stated other reasons.

For the items (B3), 62 respondents (15.5 percent) stated that they could follow 30 minutes of study, 103 respondents (25.8 percent) could follow for 40 minutes, 94 respondents (23.5 percent) could attend 50 minutes of study and 141 respondents ( 35.3 percent) can follow more than one hours. This finding shows that time more than one hour and 40 minutes is the highest period of time study among the respondents. For the items (B4) related to the position of the respondents while studies, showed that 192 respondents (48 percent) were sitting in front of the educators (ustaz), 22 
respondents (5.5 percent) prefer to sit in a circle (halaqah) and 186 respondents (46.5 percent) were in a position in comfortable spaces.

For the items (B5) related to the subjects in religious studies at the mosque, 276 respondents (69 percent) have learned the akidah studies, 279 respondents (70 percent) have studied al-Quran and tajwid, 264 respondents (66 percent ) have studied the tafsir, and 268 respondents (67 percent) have learned the hadith. A total of 263 respondents (66 percent) have learned the akhlaq, 237 respondents (60 percent) have learned the sirah subject, 267 respondents (67 percent) have studied the figh subject and 312 respondents (78 percent) have studied general subject at the mosque. This finding shows that most respondents have been following religious studies in mosques according to the specified subjects. The highest subjects the respondents have studied at the mosque are akidah, al-Quran and tajwid, tafsir and hadith as shown in Table 5.

For the items (B6) related to subjects who are interested in mosque studies. The finding shows that 166 respondents (41 percent) are interested in the study of akidah, 59 respondents (15 percent) are interested in Quran and tajwid, 46 respondents (11 percent) are interested in tafsir, 18 respondents (4.5 percent) are interested in the study of hadith, 29 respondents ( 7.2 percent) are interested in akhlaq, 27 respondents (6.8 percent) are interested in sirah, 26 respondents (6.5 percent) are interested in fiqh studies and 29 respondents percent) are interested in general topics. This shows that akidah studies are the subject of interest in religious studies at the mosques.

For items (B7) related to religious sources obtained, 279 respondents (70 percent) followed religious studies on television, 199 respondents (50 percent) followed religious studies on radio, 308 respondents (77 percent) understood religion through internet, 287 respondents (72 percent) understood religion through reading the book, 123 respondents ( 31 percent) understood through the magazine and 131 respondents (33 percent) understood religion by following usrah. This finding shows that most respondents are more likely to understand religion through electronic mediums such as browsing the internet, television and radio. 
INTERNATIONAL JOURNAL OF ACADEMIC RESEARCH IN BUSINESS AND SOCIAL SCIENCES Vol. 8, No. 12, Dec, 2018, E-ISSN: 2222-6990 @ 2018 HRMARS

Table 5. Participation of Respondent in Religious Studies at the Mosque

\begin{tabular}{|c|c|c|c|c|}
\hline Num. & Items & & Total & Percent \\
\hline B1. & $\begin{array}{l}\text { Participated in religious } \\
\text { studies at the mosque }\end{array}$ & $\begin{array}{c}\text { Often } \\
\text { (4-5 times a week) } \\
\text { Sometimes } \\
\text { (1-3 times a week) } \\
\text { Total }\end{array}$ & $\begin{array}{l}284 \\
116 \\
400\end{array}$ & $\begin{array}{c}71 \\
29 \\
100\end{array}$ \\
\hline B2. & $\begin{array}{l}\text { Problems faced to study } \\
\text { religion in the mosque }\end{array}$ & 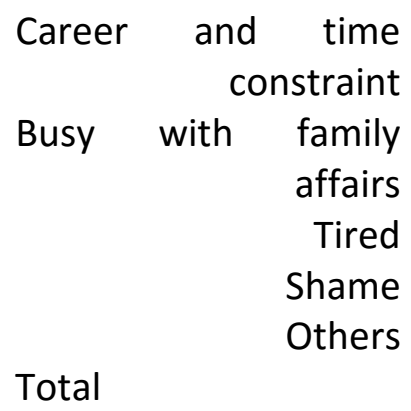 & $\begin{array}{c}143 \\
58 \\
47 \\
3 \\
149 \\
400\end{array}$ & $\begin{array}{c}35.8 \\
14.5 \\
11.8 \\
8 \\
29.9 \\
100\end{array}$ \\
\hline B3. & $\begin{array}{l}\text { Preferable in duration time for } \\
\text { learning }\end{array}$ & $\begin{array}{l}30 \text { Minutes } \\
40 \text { Minutes } \\
50 \text { Minutes } \\
1 \text { hour and above } \\
\text { Total }\end{array}$ & $\begin{array}{c}62 \\
103 \\
94 \\
141 \\
400 \\
\end{array}$ & $\begin{array}{l}15.5 \\
25.8 \\
23.5 \\
35.3 \\
100 \\
\end{array}$ \\
\hline B4. & Position during studies & $\begin{array}{l}\text { In front of educators } \\
\text { In circles (halaqah) } \\
\text { Position in } \\
\text { comfortable } \\
\text { spaces } \\
\text { Total }\end{array}$ & $\begin{array}{c}192 \\
22 \\
186 \\
400\end{array}$ & $\begin{array}{c}48.0 \\
5.5 \\
46.5 \\
100\end{array}$ \\
\hline B5. & $\begin{array}{l}\text { Subject of studies have } \\
\text { learned in the mosque }\end{array}$ & $\begin{array}{l}\text { Aqidah } \\
\text { Al-Quran and Tajwid } \\
\text { Tafsir } \\
\text { Hadith } \\
\text { Akhlaq } \\
\text { Sirah } \\
\text { Fiqh } \\
\text { General topic }\end{array}$ & $\begin{array}{l}276 \\
279 \\
264 \\
268 \\
263 \\
237 \\
267 \\
312\end{array}$ & $\begin{array}{l}69 \\
70 \\
66 \\
67 \\
66 \\
60 \\
67 \\
78\end{array}$ \\
\hline
\end{tabular}


INTERNATIONAL JOURNAL OF ACADEMIC RESEARCH IN BUSINESS AND SOCIAL SCIENCES

Vol. 8, No. 12, Dec, 2018, E-ISSN: 2222-6990 @ 2018 HRMARS

\begin{tabular}{|c|c|c|c|c|}
\hline \multirow[t]{8}{*}{ B6. } & $\begin{array}{l}\text { Subjects are interested in } \\
\text { mosque studies }\end{array}$ & Aqidah & 166 & 41 \\
\hline & & Al-Quran and Tajwid & 59 & 15 \\
\hline & & Tafsir & 46 & 11 \\
\hline & & Hadith & 18 & 4.5 \\
\hline & & Akhlak & 29 & 7.2 \\
\hline & & Sirah & 27 & 6.8 \\
\hline & & Fiqh & 26 & 6.5 \\
\hline & & General topic & 29 & 7.2 \\
\hline \multirow[t]{6}{*}{ B7. } & $\begin{array}{l}\text { Religious sources obtained } \\
\text { than mosque studies }\end{array}$ & Television & 279 & 70 \\
\hline & & Radio & 199 & 50 \\
\hline & & Internet & 308 & 77 \\
\hline & & Religious book & 287 & 72 \\
\hline & & Magazine & 123 & 31 \\
\hline & & Usrah & 131 & 33 \\
\hline
\end{tabular}

(c) Respondents Perception of Religious Studies in Mosque

Table 6 shows the findings of the respondent perceptions toward readiness aspect among the educators. The analysis showed that the mean readiness of the educators at the high level (3.77) based on mean score interpretation (3.67-5.00). This shows that the respondents perception toward readiness educators in high level. This finding suggests that most educators have excellent readiness in terms of schedule management, material arrangement and self-preparation. For items (C1), 356 respondents (89 percent) agreed the educators follow the schedule of teaching and 270 respondents (67.5 percent) agreed with the item C2, educators organize the topics on a weekly. While in the item (C3), 255 respondents (63.8 percent) agree that the educators prepare before the lecture.

In terms of teaching materials, the findings showed mean at the moderate level of 3.33 based on mean score interpretation (2.34-3.66). Item (C4) shows that 194 respondents ( 48.5 per cent) agree on the materials used and 117 respondents (29.3 per cent) state that they are uncertain whether educators prefer to use old books or not. For the items (C5), 234 respondents (58.5 percent) agreed with the educators to provide copies of teaching materials, 75 respondents (19 percent) were uncertain and 91 respondents (23 percent) disagreed. For item (C6), 332 respondents (83 percent) agreed with the educators using easy materials teaching to understanding, 42 respondents (11.5 percent) were uncertain and 56 respondents (14 percent) disagreed. This finding similar with the study of Noor Najihan Jaafar (2014) who finds registered (tauliah) educators from religious authorities using the easy material teaching with jawi books, translation books and etc. 
The findings showed mean of presentation aspect in teaching at the moderate level (3.41) based on mean score interpretation (2.34-3.66). For items (C7), 221 respondents (55.3 percent) disagree with the educators discussing repeated titles or sub-titles of subjects. For items (C8), 159 respondents (39.8 percent) agreed the educators discussing topic over an hour. For items (C9) found that 194 respondents (48.5 percent) agreed with the educators not to discuss the actual topic, 117 respondents (29.3 percent) were unsure and 89 respondents ( 22.3 percent) disagreed. This shows that most of the respondents agree that there are teachers who are not focused on actual discussions. For items (C10), the findings show that 358 respondents ( 89.5 percent) agree that educators are able to explain a topic very well. Item (C11) found that 356 respondents (89 percent) agreed that the educators has related religion aspect with the current issues.

The findings showed that the mean of perception respondents toward educator lectures at the moderate level of 3.43 based on mean score interpretation (2.34-3.67). Item (C12) found that 297 respondents (74.3 percent) disagree with the educators using inappropriate speech during teaching and 67 respondents (16.7 percent) agreed. For item (C13), 365 respondents (91.3 percent) agree that the educators always lead the prayer ( $\left.a l-d u^{\prime} a\right)$ before and after the lecture. While item (C14) finding shows that 303 respondents (75.8 percent) like the educator as favourite for religious studies in the mosque.

Table 6. Respondent Perceptions toward the Educators

\begin{tabular}{|c|c|c|c|c|c|c|c|}
\hline \multirow[t]{2}{*}{ Number } & \multirow[b]{2}{*}{ Items } & 1 & 2 & 3 & 4 & 5 & \multirow[b]{2}{*}{ Mean } \\
\hline & & $\begin{array}{l}\text { Strongly } \\
\text { not } \\
\text { Agree } \\
\text { (percent) }\end{array}$ & $\begin{array}{l}\text { Disagree } \\
\text { (percent) }\end{array}$ & $\begin{array}{l}\text { Uncertain } \\
\text { (percent) }\end{array}$ & $\begin{array}{c}\text { Agree } \\
\text { (percent) }\end{array}$ & $\begin{array}{l}\text { Strongly } \\
\text { Agree } \\
\text { (percent) }\end{array}$ & \\
\hline \multicolumn{8}{|c|}{ Perception for Readiness } \\
\hline C1. & $\begin{array}{l}\text { The educators } \\
\text { follow the } \\
\text { schedule time for } \\
\text { teaching }\end{array}$ & $\begin{array}{c}5 \\
(1.2)\end{array}$ & $\begin{array}{c}10 \\
(2.5)\end{array}$ & $\begin{array}{c}29 \\
(7.2)\end{array}$ & $\begin{array}{c}268 \\
(67.0)\end{array}$ & $\begin{array}{c}88 \\
(22.0)\end{array}$ & 4.04 \\
\hline C2. & $\begin{array}{l}\text { The educator } \\
\text { organize the } \\
\text { favourite topic for } \\
\text { audience a weekly }\end{array}$ & $\begin{array}{c}8 \\
(2.0)\end{array}$ & $\begin{array}{c}31 \\
(7.8)\end{array}$ & $\begin{array}{c}91 \\
(22.8)\end{array}$ & $\begin{array}{c}230 \\
(57.5)\end{array}$ & $\begin{array}{c}40 \\
(10.0)\end{array}$ & 3.66 \\
\hline C3. & $\begin{array}{l}\text { The educators } \\
\text { prepare before } \\
\text { the lecture }\end{array}$ & $\begin{array}{c}10 \\
(2.5)\end{array}$ & $\begin{array}{c}46 \\
(11.5)\end{array}$ & $\begin{array}{c}89 \\
(22.3)\end{array}$ & $\begin{array}{c}196 \\
(49.0)\end{array}$ & $\begin{array}{c}59 \\
(14.8)\end{array}$ & 3.62 \\
\hline \multicolumn{8}{|c|}{ Mean Average: 3.77} \\
\hline
\end{tabular}


INTERNATIONAL JOURNAL OF ACADEMIC RESEARCH IN BUSINESS AND SOCIAL SCIENCES Vol. 8, No. 12, Dec, 2018, E-ISSN: 2222-6990 @ 2018 HRMARS

\begin{tabular}{|c|c|c|c|c|c|c|c|}
\hline C4. & $\begin{array}{l}\text { The educators } \\
\text { prefer to use old } \\
\text { book (kitab jawi } \\
\text { lama). }\end{array}$ & $\begin{array}{c}28 \\
(7.0)\end{array}$ & $\begin{array}{c}69 \\
(17.3)\end{array}$ & $\begin{array}{c}63 \\
(15.8)\end{array}$ & $\begin{array}{c}35 \\
(8.8)\end{array}$ & $\begin{array}{c}10 \\
(2.5)\end{array}$ & 2.66 \\
\hline C5. & $\begin{array}{l}\text { The educator } \\
\text { provide copies of } \\
\text { material teaching }\end{array}$ & $\begin{array}{c}13 \\
(3.3)\end{array}$ & $\begin{array}{c}78 \\
(19.5)\end{array}$ & $\begin{array}{c}75 \\
(18.8)\end{array}$ & $\begin{array}{c}188 \\
(47.0)\end{array}$ & $\begin{array}{c}46 \\
(11.5)\end{array}$ & 3.44 \\
\hline c6. & $\begin{array}{l}\text { The educators use } \\
\text { the easy material } \\
\text { to understanding }\end{array}$ & $\begin{array}{c}5 \\
(1.3)\end{array}$ & $\begin{array}{c}21 \\
(5.3)\end{array}$ & $\begin{array}{c}42 \\
(10.5)\end{array}$ & $\begin{array}{c}276 \\
(69.0)\end{array}$ & $\begin{array}{c}56 \\
(14.0)\end{array}$ & 3.89 \\
\hline \multicolumn{8}{|c|}{ Mean Average: 3.33} \\
\hline \multicolumn{8}{|c|}{ Perception for Lecture } \\
\hline C7. & $\begin{array}{l}\text { The educators } \\
\text { discussing } \\
\text { repeated titles or } \\
\text { sub-titles of } \\
\text { subjects }\end{array}$ & $\begin{array}{c}44 \\
(11.0)\end{array}$ & $\begin{array}{c}177 \\
(44.3)\end{array}$ & $\begin{array}{c}98 \\
(24.5)\end{array}$ & $\begin{array}{c}72 \\
(18.0)\end{array}$ & $\begin{array}{c}9 \\
(2.3)\end{array}$ & 2.56 \\
\hline C8. & $\begin{array}{l}\text { The educator } \\
\text { discussing topic } \\
\text { over an hour }\end{array}$ & $\begin{array}{c}24 \\
(6.0)\end{array}$ & $\begin{array}{c}124 \\
(31.0)\end{array}$ & $\begin{array}{c}93 \\
(23.3)\end{array}$ & $\begin{array}{c}138 \\
(34.5)\end{array}$ & $\begin{array}{c}21 \\
(5.3)\end{array}$ & 3.02 \\
\hline C9. & $\begin{array}{l}\text { The educator not } \\
\text { discussing the } \\
\text { actual topic }\end{array}$ & $\begin{array}{c}15 \\
(3.8)\end{array}$ & $\begin{array}{c}74 \\
(18.5)\end{array}$ & $\begin{array}{c}117 \\
(29.3)\end{array}$ & $\begin{array}{c}168 \\
(42.0)\end{array}$ & $\begin{array}{c}26 \\
(6.5)\end{array}$ & 3.29 \\
\hline C10. & $\begin{array}{l}\text { The educators are } \\
\text { able to explain } \\
\text { topic very well }\end{array}$ & $\begin{array}{c}5 \\
(1.3)\end{array}$ & $\begin{array}{c}6 \\
(1.5)\end{array}$ & $\begin{array}{c}31 \\
(7.8)\end{array}$ & $\begin{array}{c}267 \\
(66.8)\end{array}$ & $\begin{array}{c}91 \\
(22.8)\end{array}$ & 4.08 \\
\hline C11. & $\begin{array}{l}\text { The educators has } \\
\text { related religion } \\
\text { aspect with the } \\
\text { current issues }\end{array}$ & $\begin{array}{c}5 \\
(1.3)\end{array}$ & $\begin{array}{c}7 \\
(1.8)\end{array}$ & $\begin{array}{c}32 \\
(8.0)\end{array}$ & $\begin{array}{c}250 \\
(62.5)\end{array}$ & $\begin{array}{c}106 \\
(26.5)\end{array}$ & 4.11 \\
\hline \multicolumn{8}{|c|}{ Mean Average: 3.41} \\
\hline \multicolumn{8}{|c|}{ Perception for Character } \\
\hline C12. & $\begin{array}{l}\text { The educators } \\
\text { using } \\
\text { inappropriate } \\
\text { speech during } \\
\text { teaching }\end{array}$ & $\begin{array}{c}120 \\
(30.0)\end{array}$ & $\begin{array}{c}177 \\
(44.3)\end{array}$ & $\begin{array}{c}36 \\
(9.0)\end{array}$ & $\begin{array}{c}47 \\
(11.8)\end{array}$ & $\begin{array}{c}20 \\
(5.0)\end{array}$ & 2.18 \\
\hline C13. & $\begin{array}{l}\text { The educators } \\
\text { always lead the }\end{array}$ & $\begin{array}{c}8 \\
(2.0)\end{array}$ & $\begin{array}{c}10 \\
(2.5)\end{array}$ & $\begin{array}{c}17 \\
(4.3)\end{array}$ & $\begin{array}{c}208 \\
(52.0)\end{array}$ & $\begin{array}{c}157 \\
(39.3)\end{array}$ & 4.24 \\
\hline
\end{tabular}


INTERNATIONAL JOURNAL OF ACADEMIC RESEARCH IN BUSINESS AND SOCIAL SCIENCES Vol. 8, No. 12, Dec, 2018, E-ISSN: 2222-6990 @ 2018 HRMARS

\begin{tabular}{|c|c|c|c|c|c|c|c|}
\hline & $\begin{array}{l}\text { prayer }\left(a l-d u^{\prime} a\right) \\
\text { before and after } \\
\text { the lecture }\end{array}$ & & & & & & \\
\hline C14. & $\begin{array}{l}\text { I like the educator } \\
\text { as favourite } \\
\text { teacher in } \\
\text { religious studies } \\
\text { at the mosque }\end{array}$ & $\begin{array}{c}5 \\
(1.3)\end{array}$ & $\begin{array}{c}13 \\
(3.3)\end{array}$ & $\begin{array}{c}79 \\
(19.8)\end{array}$ & $\begin{array}{c}230 \\
(57.5)\end{array}$ & $\begin{array}{c}73 \\
(18.3)\end{array}$ & 3.88 \\
\hline
\end{tabular}

Besides that, hypothesis testing was conducted to obtain significant value in the variables. For the hypothesis $(\mathrm{H} 1)$, there are not significant difference in the mean score of the respondents perceptions based on gender on the educator personality. The $t$ test (independent sample t test) was conducted to determine the difference. The results showed that no significant difference $(P=0.088$, $\mathrm{p}<0.05$ ) between male respondents (mean $=3.00, \mathrm{sd}=0.64628)$ and female (mean $=3.11$, $s d=$ 0.71280 ) towards the educators personality of religious studies in mosques as shown in Table 7. Thus, the null hypothesis is rejected.

Table 7. T Test for $\mathrm{H1}$

\begin{tabular}{|l|c|c|c|c|c|}
\hline Respondent & $\mathbf{N}$ & Mean & S.D & $\boldsymbol{t}$ & Sig. (2-tailed) \\
\hline Male & 317 & 3.00 & 0.64628 & -1.328 & 0.088 \\
\hline Female & 83 & 3.11 & 0.71280 & -1.254 & \\
\hline
\end{tabular}

* Significant at level of $\mathrm{P}<0.05$

$\mathrm{H}$ 2: There are not significant difference in the mean score perceptions of respondent age and the materials used by educator.

A One-Way Analysis of Variance (ANOVA) test was conducted to identify the significant difference and material used by educator. The results showed that there was a significant difference $(P=0.000$, $\mathrm{P}<0.05)$ respondents age based and the material used by educator as shown in Table 8 . Therefore, null hypothesis was accepted.

Table 8. ANOVA test for $\mathrm{H} 2$

\begin{tabular}{|c|c|c|c|c|c|}
\hline Variation & $\begin{array}{c}\text { Total } \\
\text { Power } \\
\text { of Two }\end{array}$ & Df & Varian & F & Sig.P \\
\hline Between Group & 18.439 & 5 & 4.610 & 5.145 & $0.000^{*}$ \\
\hline Within Group & 353.921 & 394 & 0.896 & & \\
\hline Total & 372.360 & 399 & & & \\
\hline
\end{tabular}

* Significant at level of $\mathrm{P}<0.05$ 
Therefore, Scheffe post hoc tests were conducted to identify the significant differences in age groups of respondents with materials used by educators. The results showed that there were significant differences $(p=0.001, p=0.024, p=0.001, p=0.024, P<0.05)$. Respondents from 31 to 40 years old $(\mathrm{min}=2.98$ ) and respondents aged 51 years and above ( $\min =3.24)$ had significant mean score on materials used by educators as shown in Table 9.

Table 9. Post-Hoc Scheffe test for $\mathrm{H} 2$

\begin{tabular}{|c|c|c|c|c|c|c|c|}
\hline Age Group & $\mathbf{N}$ & Mean & $<\mathbf{2 0}$ & $\mathbf{2 1 - 3 0}$ & $\mathbf{3 1 - 4 0}$ & $\mathbf{4 1 - 5 0}$ & $\mathbf{5 1}>$ \\
\hline $\begin{array}{c}\text { Under 20 years } \\
\text { old }\end{array}$ & 10 & 3.50 & & & & & \\
\hline 21-30 years old & 61 & 3.72 & & & $0.001^{*}$ & & $0.024^{*}$ \\
\hline $31-40$ years old & 68 & 2.98 & & & $0.001^{*}$ & & \\
\hline $41-50$ years old & 90 & 3.28 & & & & & \\
\hline $\begin{array}{c}51 \text { years old and } \\
\text { above }\end{array}$ & 171 & 3.24 & & $0.024^{*}$ & & & \\
\hline Total & 400 & 3.29 & & & & & \\
\hline
\end{tabular}

* Significant at level of $\mathrm{P}<0.05$

$\mathrm{H} 3$ : There are not significant difference in the mean score of the respondents perceptions based on the educational background with the teaching method.

A One-Way Analysis of Variance (ANOVA) test were conducted to identify the significant difference perceptions based on the educational background toward the teaching method among educators. The results showed that there were differences $(P=0.000, P<0.05)$ based on the respondents age based on the teaching method as shown in Table 10. Thus, the null hypothesis was accepted.

Table 10. ANOVA test for $\mathrm{H3}$

\begin{tabular}{|c|c|c|c|c|c|}
\hline Variation & $\begin{array}{c}\text { Total } \\
\text { Power } \\
\text { of Two }\end{array}$ & Df & Varian & F & Sig.P \\
\hline Between Group & 16.826 & 5 & 3.365 & $\begin{array}{c}10.39 \\
6\end{array}$ & $0.000^{*}$ \\
\hline Within Group & 127.539 & 394 & 0.324 & & \\
\hline Total & 144.365 & 399 & & & \\
\hline
\end{tabular}

* Significant at level of $\mathrm{P}<0.05$

Thus, Scheffe's post hoc test was conducted to identify the differences in the background of a significant respondent education background by teaching method. The results showed that there were significant differences $(p=0.000, p=0.001, p=0.002, p=0.008, P<0.05)$. The results showed that the respondents of the pondok or madrasah schools ( $\mathrm{min}=3.21)$, SPM or SPVM (mean $=3.61)$, diploma or STPM (mean $=4.06)$ and bachelor or master ( $\min =4.07$ ) have a significant mean difference in the materials used by educator as shown in Table 11. 
INTERNATIONAL JOURNAL OF ACADEMIC RESEARCH IN BUSINESS AND SOCIAL SCIENCES

Vol. 8, No. 12, Dec, 2018, E-ISSN: 2222-6990 @ 2018 HRMARS

Table11. Post-Hoc Scheffe test for H3

\begin{tabular}{|c|c|c|c|c|c|c|c|c|}
\hline Variation & $\mathbf{N}$ & Mean & UP & $\begin{array}{c}\text { DIP/ } \\
\text { STPM }\end{array}$ & $\begin{array}{l}\text { SPM/ } \\
\text { SPVM }\end{array}$ & $\begin{array}{l}\text { SRP/ } \\
\text { PMR }\end{array}$ & PM & PS \\
\hline Bachelor or Postgraduate (UP) & 135 & 4.07 & & & $\begin{array}{l}0.000 \\
*\end{array}$ & & $\begin{array}{c}0.000 \\
*\end{array}$ & \\
\hline Diploma or STPM & 122 & 4.06 & & & $\begin{array}{l}0.000 \\
*\end{array}$ & & $\begin{array}{c}0.001 \\
*\end{array}$ & \\
\hline SPM or SPVM & 63 & 3.61 & $\begin{array}{l}0.000 \\
*\end{array}$ & $\begin{array}{c}0.000 \\
*\end{array}$ & & $0.008^{*}$ & & \\
\hline SRP or PMR & 58 & 4.03 & & & & & & \\
\hline Pondok or madrasah (PM) & 11 & 3.21 & & & $\begin{array}{c}0.008 \\
*\end{array}$ & & $\begin{array}{c}0.002 \\
*\end{array}$ & \\
\hline Primary School (PS) & 11 & 3.88 & & & & & & \\
\hline Total & 400 & 3.96 & & & & & & \\
\hline
\end{tabular}

* Significant at level of $\mathrm{P}<0.05$

H4: There are not significant difference in the mean score of perceptions respondents based on employment and time participation in religious studies at the mosque.

A One-Way Analysis of Variance (ANOVA) test were conducted to identify significant difference in the mean score of perceptions respondents based on employment and time participation in religious studies at the mosque. The results showed that there were differences $(P=0.000, P<0.05)$ based on employment and time participation in religious studies at the mosque as shown in Table 12. Therefore, the null hypothesis was accepted.

Table 12. ANOVA test for $\mathrm{H} 4$

\begin{tabular}{|c|c|c|c|c|c|}
\hline Variation & $\begin{array}{c}\text { Total } \\
\text { Power } \\
\text { of Two }\end{array}$ & Df & Varian & F & Sig.P \\
\hline Between Group & 108.360 & 3 & 36.120 & $\begin{array}{c}24.18 \\
5\end{array}$ & $0.000^{*}$ \\
\hline Within Group & 591.418 & 396 & 1.493 & & \\
\hline Total & 699.778 & 399 & & & \\
\hline
\end{tabular}

* Significant at level of $\mathrm{P}<0.05$

Therefore, Scheffe post hoc tests were conducted to identify the differences in the group of significant respondents with time participation in religious studies at the mosque. The results showed that there were significant differences $(p=0.000, p=0.001, p=0.002, p=0.008, P<0.05)$. The results showed that the respondents of the pondok or madrasah schools (mean $=3.21$ ), SPM or SPVM (mean $=3.61$ ), diploma or STPM (mean $=4.06$ ) and bachelor or master (mean $=4.07$ ) significant to materials used by educators as shown in Table 13. 
INTERNATIONAL JOURNAL OF ACADEMIC RESEARCH IN BUSINESS AND SOCIAL SCIENCES

Vol. 8, No. 12, Dec, 2018, E-ISSN: 2222-6990 @ 2018 HRMARS

Table 13. Scheffe post hoc tests for H4

\begin{tabular}{|l|c|c|c|c|c|c|}
\hline \multicolumn{1}{|c|}{ Education Background } & N & Mean & GS & P & SE & R \\
\hline Government Servant (GS) & 127 & 2.88 & & $\begin{array}{c}0.016 \\
*\end{array}$ & & \\
\hline Private (P) & 97 & 2.35 & $\begin{array}{c}0.016 \\
*\end{array}$ & & $0.000^{*}$ & $\begin{array}{c}0.000 \\
*\end{array}$ \\
\hline Self-employed (SE) & 80 & 3.21 & & $\begin{array}{c}0.000 \\
*\end{array}$ & & \\
\hline Retire (R) & 96 & 3.80 & $\begin{array}{c}0.000 \\
*\end{array}$ & $\begin{array}{c}0.000 \\
*\end{array}$ & $0.019 *$ & \\
\hline Total & 400 & 3.04 & & & & \\
\hline
\end{tabular}

* Significant at level of $\mathrm{P}<0.05$

H5: The readiness of educators has no significant correlation with lecture methods

The pearson correlation test were conducted for $\mathrm{H} 6$ and showed that there was a significant relationship $(P=0.005, P<0.05)$ the readiness of educator with lecture method as shown in Table 13. Hence, the null hypothesis $\mathrm{H} 6$ was accepted. The findings showed that there were positive relationships $(r=250, p<0.05)$ and significant with the perception of educators readiness with lecture method. That means the highest of mean score of readiness increased score of the lecture method. The result indicates that educator readiness has a positive implication on lecture method.

Table 13. Correlation test for $\mathrm{H} 5$

\begin{tabular}{|c|c|c|}
\hline \multicolumn{2}{|c|}{ Pearson } & Sig. (2-tailed) \\
\hline Readiness & 0.250 & $0.000^{*}$ \\
\hline Lecture method & 0.250 & $0.000^{*}$ \\
\hline
\end{tabular}

* Significant at level of $\mathrm{P}<0.05$

Therefore, in Table 14 describes the hypothesis testing of respondents perceptions of religious teaching in the mosque. The $\mathrm{H} 1$ test was conducted with a $t$ test involving the differences of two gender groups. $\mathrm{H} 2, \mathrm{H} 3, \mathrm{H} 4$ and $\mathrm{H} 5$ tests are carried out by ANOVA test based on educational background, age and employment. While the $\mathrm{H} 6$ test was carried out with pearson correlation test based on the relationship between the aspect of readiness and the method of lecture. 
INTERNATIONAL JOURNAL OF ACADEMIC RESEARCH IN BUSINESS AND SOCIAL SCIENCES

Vol. 8, No. 12, Dec, 2018, E-ISSN: 2222-6990 @ 2018 HRMARS

Table 14. Summuries for Hypothesis Test

\begin{tabular}{|l|l|l|}
\hline \multicolumn{1}{|c|}{ Hypothesis } & \multicolumn{1}{c|}{ Tests } & \multicolumn{1}{c|}{ Result } \\
\hline $\begin{array}{l}\mathrm{H} 1: \text { There are not significant difference in the mean } \\
\text { score of the respondents perceptions based on gender } \\
\text { towards the teaching personality. }\end{array}$ & $\begin{array}{l}\text { T Test - } \\
\text { Independent } \\
\text { sample t test }\end{array}$ & $\mathrm{H}^{\circ}$ rejected \\
\hline $\begin{array}{l}\mathrm{H} 2: \text { There are not significant difference in the mean } \\
\text { score of respondents age perceptions based on the age } \\
\text { of the materials used by the educators. }\end{array}$ & $\begin{array}{l}\text { ANOVA - } \\
\text { post hoc } \\
\text { scheffe }\end{array}$ & $\mathrm{H}^{\circ}$ accepted \\
\hline $\begin{array}{l}\mathrm{H} 3: \mathrm{H} \text { : There are not significant difference in the } \\
\text { mean score of the respondents perceptions based on } \\
\text { the educational background of the teaching method. }\end{array}$ & $\begin{array}{l}\text { ANOVA - } \\
\text { post hoc } \\
\text { scheffe }\end{array}$ & $\mathrm{H}^{\circ}$ accepted \\
\hline $\begin{array}{l}\mathrm{H} 4: \text { There are not significant difference in mean score } \\
\text { of respondents perceptions based on employment and } \\
\text { time of religious studies at the mosque. }\end{array}$ & $\begin{array}{l}\text { ANOVA - } \\
\text { post hoc } \\
\text { scheffe }\end{array}$ & $\mathrm{H}^{\circ}$ accepted \\
\hline $\begin{array}{l}\mathrm{H} 5: \text { The readiness of educators has no significant } \\
\text { correlation with lecture methods. }\end{array}$ & $\begin{array}{l}\text { Correlation - } \\
\text { pearson }\end{array}$ & $\mathrm{H}^{\circ}$ accepted \\
\hline
\end{tabular}

\section{Conclusion}

Based on the discussion, religious studies at mosques have contributed positively to lifelong learning in Malaysia. Religious studies at the mosque have had a positive impact on the Muslim community for increasing the knowledge or understanding of Islam and increasing religious quality life based on the shari'a. The results of the study show that the implementation of religious studies in the mosque is still positively accepted among the Muslim community. The findings show that participation still in moderate level especially in terms of employment, time and other constraints. Meanwhile, the findings of the respondents perceptions analysis on the readiness of the educators showed the mean value in the high level (mean $=3.77$ ), the perception of the teaching materials in the moderate (mean $=3.33$ ), the perception of the lecture method in the moderate level (mean $=3.41$ ) and perception toward character of educators in the moderate level (mean $=3.43$ ). In addition, there was no significant difference $(p=0.088, p<0.05)$ perceptions between male and female respondents toward the educators character. That means gender does not differentiate in the need to understanding of Islam through religious studies at the mosques. While one way variant analysis test also found that there was a significant difference $(P=0.000<P=0.05)$ perception of age based respondents to teaching materials used. Similarly, there was a significant difference $(P=0.000, P<0.05)$ respondents perception based on the time of participating in religious studies at the mosque. Correlation analysis also found that there was a positive correlation $(r=250, p<0.05)$ with the perception of educators readiness and the lecture method. The results showed that there were implications for the implementation of religious studies in the mosque. The findings show that religious studies in mosques provide important values to religious life among the Muslim community including gender, age, education and employment background. However, the need to build a new and dynamic model in religious studies at the mosque. It covers aspects of life-long learning curriculum or adult learning, educators and understanding of subjects that needs of the current Muslim community. 
INTERNATIONAL JOURNAL OF ACADEMIC RESEARCH IN BUSINESS AND SOCIAL SCIENCES

Vol. 8, No. 12, Dec, 2018, E-ISSN: 2222-6990 @ 2018 HRMARS

\section{Acknowledgement}

Data part of this article under the Research Grant of Top Down KPT (Fundamental) UPSI. Research Grant code - 2016-0218-107-41.

\section{Corresponding Author}

Abd Hadi Borham, Faculty of Human Sciences, Sultan Idris Education University (UPSI), Malaysia. Email: abdhadi.borham@fsk.upsi.edu.my

\section{References}

Abd Hadi, B. \& Zukiple, A.G. (2015). The pattern of internet exposure and its impact towards understanding Islam among academicians in UKM and USIM. Malaysian Journal of Communication, 31 (2), 404-421.

Al-Bukhari, A.M.I. (1987). Sahih al-Bukhari. In Al-Rifa'ie, al-Sheikh Qāsim al-Shama'ie (Ed.) Beirut: Dar al-Qalam.

Alias, A. (2013). Contemporary fiqh learning module at mosque in Malaysia. International Journal for Educational Studies, 6 (2), 69-78.

Al-Na'miy, A.A. (1994). kaedah dan teknik pengajaran menurut Ibn Khaldun dan al-Qabisi. (Trans.) Mohd Ramzi Omar. Kuala Lumpur: Dewan Bahasa dan Pustaka.

Chua, Y.P. (2006). Kaedah Penyelidikan, Buku 1. Kuala Lumpur: Mc Graw Hill (Kuala Lumpur).

Engku, A.Z.E.A. (2008). Pengajian Takmir Masjid di Terengganu. Jurnal Islam \& Masyarakat Kontemporari, 1(1), 7-21.

Fakhrul Adabi, A.K. (2007). Keberkesanan kelas agama di masjid daerah Hulu Langat Selangor. Jurnal Usuluddin, 25 (2), 73-88.

Fauzi, H., Jamal, A. \& Mohd, S. (2014). Kaedah Penyelidikan \& Analisis Data SPSS. Sintok, Kedah: Penerbit Universiti Utara Malaysia

Mc Culloch. (2014). Understanding teaching and learning in primary education. United Kingdom: SAGE Publications Ltd.

Mohd Sheffie, A.B. (1991). Metodologi Penyelidikan. Bangi: Penerbit Universiti Kebangsaan Malaysia (UKM).

Mohd. Muhiden, A.R \& Mohd Alwee, Y. (2009). Masjid sebagai Sebuah Institusi Pendidikan: Suatu Tinjauan dari Aspek Sejarah. In Ahmad Najib, A. (Ed.), Isu-Isu Pengurusan dan Pembangunan Masjid. (pp 1-12). Nilam Puri: Akademi Pengajian Islam.

Noor Najihan, J. (2014). Pelaksanaan Kelas Pengajian Tafsir Al-Quran dan Hadith: Kajian terhadap Beberapa Masjid Terpilih Sekitar Nilai dan Wilayah Persekutuan. Retrived from http://ddms.usim.edu.my/handle/123456789/7461.

Omar, Z. (2012). Penggunaan Kitab dalam Komunikasi Dakwah: Kajian Kes Terhadap Pengajian Agama di Masjid dan Surau di Selangor dan Negeri Sembilan. (Unpublish, Thesis Doctor of Philosophy). Fakulti Sastera dan Sains Sosial. Universiti Malaya.

Panduan Program Takmir Masjid dan Surau Seluruh Malaysia. (2012). Putrajaya: Jabatan Kemajuan Islam Malaysia (JAKIM). 
Rahim, M.M.A. Borham, A.H \& Hashim, A. (2018). Ability in Comprehending Meaning of the Quranic Verses among Tahfiz Students. International Journal of Academic Research in Business \& Social Sciences. 8(11), 1646-1656.

Shanaz, H. (2004). The Muslim Conquest of Spain and The Legacy of Al-Andalus. London: Taha Publishers Ltd.

Sheikh Ali, M.M. (1997). Peranan Masjid dalam Islam (Trans.) Kuala Lumpur: Yayasan Dakwah Islamiah Malaysia (YADIM).

Shuhadak, M. \& Ibnor Azli, I. (2014). Pelaksanaan Program Takmir sebagai Medium Pengimarahan Masjid di Negeri Sembilan. Jurnal Al-Hikmah, 6 (2), 53-64. 